\title{
Deoxyribonucleic Acid Relatedness Among Mycobacterium leprae, Mycobacterium lepraemurium, and Selected Bacteria by Dot Blot and Spectrophotometric Deoxyribonucleic Acid Hybridization
}

\author{
Assays \\ R. S. ATHWAL, S. S. DEO, AND T. IMAEDA* \\ Department of Microbiology, UMDNJ-New Jersey Medical School, Newark, New Jersey 07103
}

\begin{abstract}
Deoxyribonucleic acid relatedness between Mycobacterium leprae or Mycobacterium lepraemurium and other selected bacteria was studied by both dot blot and spectrophotometric deoxyribonucleic acid hybridization assays. The results obtained by the two methods were similar, except for the relatedness values between $M$. leprae and two corynebacterial strains. Among the mycobacterial species examined, acid-fast organisms isolated from armadillos and a mangabey monkey with leprosy-like disease showed $100 \%$ relatedness with $M$. leprae grown experimentally in armadillos, suggesting their common origin. In this study we demonstrate the usefulness of the dot blot hybridization technique as a screening method for mycobacterial taxonomy.
\end{abstract}

The deoxyribonucleic acids (DNAs) of Mycobacterium leprae and Mycobacterium lepraemurium were analyzed kinetically to determine their genome sizes, base ratios, and genetic relatedness to certain corynebacteria, mycobacteria, and nocardiae $(5,6)$. M. leprae grown in armadillos was found to be a unique organism among the CorynebacteriumMycobacterium-Nocardia group, whereas $M$. lepraemurium grown in mice showed close genetic relatedness to Mycobacterium avium. These studies demonstrated the usefulness of DNA relatedness values in taxonomic or phylogenetic studies of the corynebacteria, mycobacteria, and nocardiae. However, one of the disadvantages of the kinetic analysis used in these studies was the requirement for extremely purified DNA samples in amounts of at least $1 \mathrm{mg}$ to determine the DNA relatedness between the test species and 20 other organisms. On the other hand, the dot blot hybridization method (7) requires neither extreme purity nor large amounts of DNA samples. Since the supply of $M$. leprae is seriously limited, this latter method facilitates the study of the DNA relatedness of this organism. In this study we determined the DNA relatedness between $M$. leprae or $M$. lepraemurium and other selected organisms belonging to the Corynebacterium-Mycobacterium-Nocardia group by using dot blot hybridization as a screening test in comparison with a spectrophotometric assay.

\section{MATERIALS AND METHODS}

Bacterial strains and culture conditions. The bacterial strains used in this study and their sources are listed in Tables 1 and 2 . The $M$. leprae strain which was used as the standard strain in the kinetic analysis and also as a source of the labeled probe in dot blot hybridization experiments was isolated from cutaneous nodules of armadillo A24 infected with $M$. leprae of human origin. This tissue was prepared by E. E. Storr, Medical Research Institute of Florida Institute of Technology, and was supplied through the National Institute of Allergy and Infectious Diseases. An acid-fast organism, which is listed as $M$. leprae (indigenous) in Table 1 , was isolated from spleen tissues of two wild armadillos (armadillos V11 and V69) with leprosy-like disease. These infected tissues were supplied by W. F. Kirchheimer, Na-

\footnotetext{
* Corresponding author.
}

tional Hansen's Disease Center. The acid-fast organism listed as $M$. leprae (Mangabey monkey) was isolated from spleen tissue of a mangabey monkey with leprosy-like disease, which was supplied by W. M. Meyers, Armed Forces Institute of Pathology (8). M. lepraemurium was isolated from mesenteric lymph nodes of mice infected with $M$. lepraemurium for 4 months. All other mycobacterial and nocardial strains were grown in Middlebrook $7 \mathrm{H} 9$ medium containing $1 \%$ glycerol, $0.05 \%$ Tween 80 , and $0.25 \%$ bovine serum albumin fraction V (Sigma Chemical Co.) at $37^{\circ} \mathrm{C}$ with constant shaking. The corynebacteria and Escherichia coli were grown in tryptic soy broth (Difco Laboratories) at $37^{\circ} \mathrm{C}$ with constant shaking.

Preparation of DNA samples. The preparation of DNA samples from bacterial cells grown in vivo or in vitro has been described previously (6). The DNA samples in $0.1 \times$ SSC $(1 \times \mathrm{SSC}$ is $0.15 \mathrm{M} \mathrm{NaCl}$ plus $0.015 \mathrm{M}$ sodium citrate, pH 7.0) were further sheared with a Heat Systems model W10 sonicator for $15 \mathrm{~s}$. The fragment size of each sheared DNA was determined by electrophoresis in a $1 \%$ agarose gel (type II; Sigma) with $0.04 \mathrm{M}$ tris(hydroxymethyl)aminomethane acetate buffer containing $0.0002 \mathrm{M}$ ethylenediaminetetraacetate $(\mathrm{pH} 8.0)$.

Spectrophotometric assay of DNA-DNA hybridization. Genome sizes and levels of DNA relatedness were estimated by using the $C_{0} t_{0.5}$ value as a parameter; this value was obtained by spectrophotometric assay of DNA-DNA hybridization with slight modifications of a previously described procedure (6). In this study, two DNA samples were mixed at an equimolar ratio instead of in equal concentrations. The reaction mixture (final concentration, $75 \mu \mathrm{g} / \mathrm{ml}$ ) was denatured at $96^{\circ} \mathrm{C}$ and then reassociated at $68^{\circ} \mathrm{C}$, which is the optimal hybridization temperature for mycobacterial DNAs. The degree of hypochromic shift during hybridization of heterologous DNA samples is proportional to the average of the reaction rates of both heterologous and homologous duplex formation (3). Therefore, we hypothesize that the DNA relatedness value between two species (species $A$ and B) implies the average DNA relatedness between species $A$ or $\mathrm{B}$ and the presumptive species which has an average genome size of species A and B. In general, the relatedness value $(h)$ between species $\mathbf{A}$ (genome size, $\left.\mathbf{A} \times 10^{9}\right)$ and $\mathbf{B}$ (genome size, $\left.\mathrm{B} \times 10^{9}\right)$ may indicate that $(\mathrm{A}+\mathrm{B}) h / 2 \mathrm{~A} \%$ of 
TABLE 1. Genome molecular weights and levels of DNA relatedness observed with $M$. leprae and selected bacteria (kinetic analysis)

\begin{tabular}{|c|c|c|c|}
\hline Organism & $\begin{array}{l}\text { Genome mol wt } \\
\qquad\left(10^{9}\right)\end{array}$ & $\begin{array}{c}\text { \% Relatedness with } \\
M . \text { leprae }\end{array}$ & $\begin{array}{c}\text { Ratio of homology } \\
\text { (M. leprae/test } \\
\text { organism) }\end{array}$ \\
\hline M. leprae (experimental) & 1.7 & 100 & \\
\hline$M$. leprae (indigenous) & 1.6 & 100 & \\
\hline M. leprae (mangabey monkey) & 1.8 & 100 & \\
\hline M. tuberculosis TMC $102^{a}$ & 1.9 & 21 & $22 / 20$ \\
\hline M. bovis BCG TMC $1011^{a}$ & 1.9 & 25 & $26 / 23$ \\
\hline M. marinum TMC $1218^{a}$ & 2.5 & 26 & $32 / 22$ \\
\hline M. intracellulare TMC $1406^{a}$ & 2.0 & 17 & $18 / 16$ \\
\hline M. gordonae TMC $1324^{a}$ & 2.8 & 15 & $20 / 12$ \\
\hline M. lepraemurium (Hawaiian) $b$ & 1.8 & 20 & $20 / 19$ \\
\hline M. scrofulaceum TMC $1323^{a}$ & 2.4 & 13 & $16 / 11$ \\
\hline M. kansasii $\mathrm{TMC} 1204^{a}$ & 3.0 & 13 & $18 / 10$ \\
\hline M. vaccae ATCC $15483^{\mathrm{Tc}}$ & 2.5 & 13 & $16 / 11$ \\
\hline M. avium TMC $706^{a}$ & 2.3 & 7 & $8 / 6$ \\
\hline $\begin{array}{l}\text { Mycobacterium sp. } \\
\text { strain } \text { ICRC }^{d}\end{array}$ & 3.0 & 9 & $12 / 7$ \\
\hline $\begin{array}{l}\text { N. otitidis-caviarum } \\
\text { ATCC } 14629^{\mathrm{T}}\end{array}$ & 3.2 & 10 & $14 / 8$ \\
\hline $\begin{array}{l}\text { Corynebacterium minutissimum } \\
\text { ATCC } 23348\end{array}$ & 1.4 & 28 & $25 / 31$ \\
\hline $\begin{array}{l}\text { Corynebacterium } \\
\text { sp. strain } 2628 \mathrm{LB}^{e}\end{array}$ & 1.1 & 20 & $16 / 25$ \\
\hline E. coli $\mathrm{K}-12$ ATCC 23724 & 2.5 & 6 & $7 / 5$ \\
\hline
\end{tabular}

a TMC, Trudeau Mycobacterial Collection. These strains were supplied by the National Jewish Hospital, Denver, Colo., through the National Insitute of Allergy and Infectious Diseases.

$b$ This organism was grown in mice (5)

c ATCC, American Type Culture Collection. T = type strain.

${ }^{d}$ This organism was isolated from a leprosy patient (1) in the Indian Cancer Research Center and was maintained by L. Barksdale at the New York University Medical Center.

${ }^{e}$ This strain of Corynebacterium was isolated from a lepromatois leprosy patient (2).

species $\mathrm{A}$ and $(\mathrm{A}+\mathrm{B}) h / 2 \mathrm{~B} \%$ of species $\mathrm{B}$ are homologous. For example, $33.3 \%$ relatedness between species $A$ (genome size, $1.5 \times 10^{9}$ ) and species $\mathrm{B}$ (genome size, $3.0 \times 10^{9}$ ) means that one-half of genome $A$ is homologous to onequarter of genome B.

Dot blot hybridization. Dot blot hybridization was performed by the method of Kafatos et al. (7), with slight modifications. Namely, DNA samples in $0.1 \times$ SSC were denatured with $3 \mathrm{~N} \mathrm{NaOH}$ for $10 \mathrm{~min}$ at room temperature and then neutralized with $3 \mathrm{~N} \mathrm{HCl}$. Samples $(100,50,25,10$, and $1 \mathrm{ng}$ ) were filtered through a nitrocellulose sheet placed on a dot blot apparatus (Schleicher \& Schuell Inc.) and baked for $2 \mathrm{~h}$ at $80^{\circ} \mathrm{C}$. ${ }^{32} \mathrm{P}$-labeled DNA probes were prepared from 1- $\mu \mathrm{g}$ DNA samples by the method of Rigby et al.

TABLE 2. Genome molecular weight and levels of DNA relatedness observed with $M$. lepraemurium and selected bacteria (kinetic analysis)

\begin{tabular}{|c|c|c|c|}
\hline Organism & $\begin{array}{l}\text { Genome mol wt } \\
\left(10^{9}\right)\end{array}$ & $\begin{array}{c}\% \text { Relatedness with } \\
M . \text { lepraemurium }\end{array}$ & $\begin{array}{c}\text { Ratio of homology } \\
(M \text {. lepraemurium/ } \\
\text { test organism) }\end{array}$ \\
\hline M. avium TMC 701 & 2.7 & 87 & $100 / 73$ \\
\hline M. avium TMC 706 & 2.3 & 87 & $99 / 78$ \\
\hline M. avium TMC 721 & 2.6 & 85 & $100 / 72$ \\
\hline M. microti TMC 1601 & 2.1 & 87 & $94 / 81$ \\
\hline M. intracellulare TMC 1403 & 2.4 & 47 & $55 / 41$ \\
\hline M. intracellulare TMC 1406 & 2.0 & 27 & $29 / 26$ \\
\hline M. kansasii TMC 1201 & 2.6 & 40 & $49 / 34$ \\
\hline M. vaccae ATCC $15483^{\mathrm{T}}$ & 2.5 & 35 & $42 / 30$ \\
\hline M. scrofulaceum TMC 1323 & 2.4 & 23 & $27 / 20$ \\
\hline M. gordonae TMC 1324 & 2.8 & 25 & $32 / 21$ \\
\hline M. bovis ATCC $19210^{\mathrm{T}}$ & 1.7 & 27 & $26 / 28$ \\
\hline M. tuberculosis TMC 102 & 1.9 & 14 & $14 / 14$ \\
\hline M. marinum TMC 1218 & 2.5 & 19 & $23 / 16$ \\
\hline M. fortuitum TMC 1529 & 2.0 & 25 & $26 / 24$ \\
\hline M. microti TMC 1608 & 1.9 & 9 & $10 / 8$ \\
\hline M. smegmatis TMC 1515 & 3.0 & 11 & $15 / 9$ \\
\hline $\begin{array}{l}\text { N. otitidis-caviarum } \\
\text { ATCC } 14629^{\mathrm{T}}\end{array}$ & 3.2 & 10 & $13 / 8$ \\
\hline C. minutissimum ATCC 23348 & 1.4 & 11 & $10 / 12$ \\
\hline E. coli $\mathrm{K}-12$ ATCC 23724 & 2.5 & 3 & $4 / 3$ \\
\hline
\end{tabular}




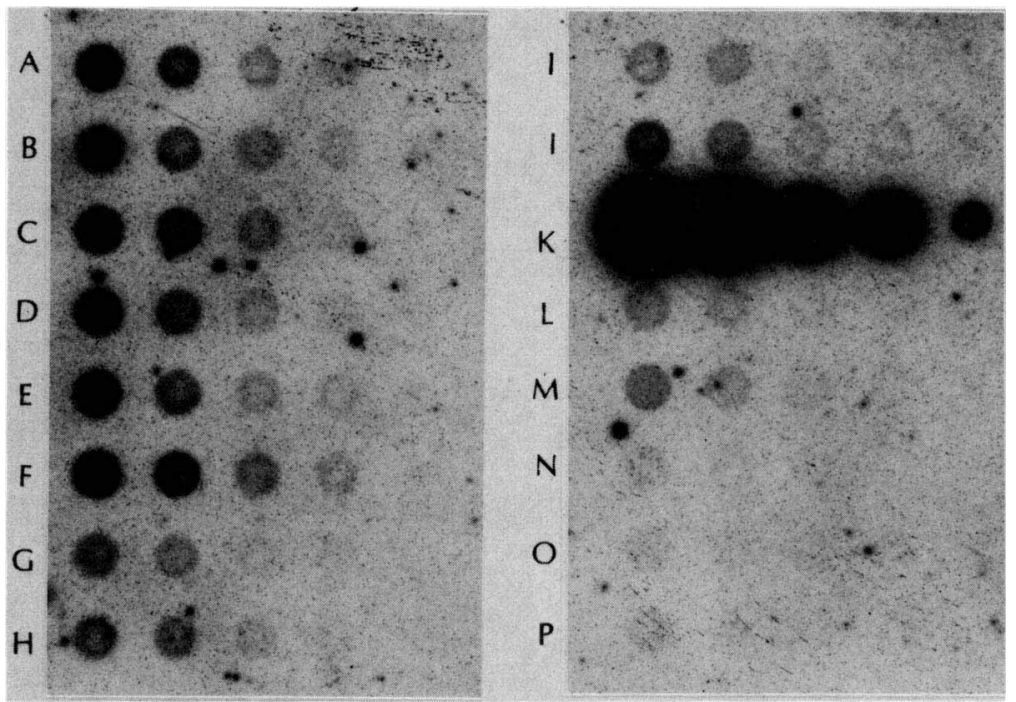

FIG. 1. Dơt blot hybridization on a nitrocellulose filter. Denatured DNA samples $(100,50,25,10$, and $1 \mathrm{ng}$ from left to right) were dotted onto a nitrocellulose filter and hybridized with an $M$. leprae DNA probe, as described in the text. Lane A, $M$. lepraemurium; lane B, $M$. avium TMC 706; lane C, $M$. intracellulare TMC 1406; lane D, Mycobacterium sp. strain ICRC; lane E, $M$. scrofulaceum TMC 1323; lane F, $M$. tuberculosis TMC 102; lane G, M. gordonae TMC 1324; lane H, M. marinum TMC 1218; lane I, M. smegmatis TMC 1515; lane J, M. kansasii TMC 1204; lane K, $M$. leprae; lane L, $M$. fortuitum TMC 1529; lane M, $M$. vaccae ATCC $15483^{\mathrm{T}}$; lane N, $C$. minutissimum ATCC $23348 ;$ lane O, Corynebacterium sp. strain 2628LB; lane P, E. coli ATCC 23724. The X-ray film was exposed for 7 days.

(9). The filter was hybridized with a ${ }^{32} \mathrm{P}$-labeled probe derived from $M$. leprae or $M$. lepraemurium $\left(5 \times 10^{4}\right.$ $\mathrm{cpm} / \mathrm{cm}^{2}$ of filter surface) in a solution containing $50 \%$ deionized formamide (Eastman Kodak Co.), $0.01 \%$ bovine serum albumin fraction V (Sigma), 0.01\% Ficoll (Sigma), $0.01 \%$ polyvinylpyrrolidone (Sigma), $5 \times \mathrm{SSC}, 0.02 \mathrm{M}$ sodium phosphate buffer $(\mathrm{pH} 6.5)$, and $10 \%$ dextran sulfate (Sigma) for $18 \mathrm{~h}$ at $42^{\circ} \mathrm{C}$. This hybridization temperature is slightly less stringent to mycobacterial DNAs. After hybridization the filter was rinsed with $2 \times$ SSC and washed for 1 to $2 \mathrm{~h}$ in three changes of $0.2 \times$ SSC containing $0.1 \%$ sodium dodecyl sulfate (Sigma) at $50^{\circ} \mathrm{C}$. The washed filter was air dried and then exposed to X-ray film for 2 to 7 days at $-70^{\circ} \mathrm{C}$. The degree of hybridization on the nitrocellulose filter was estimated by comparing the intensities of signals of lower concentrations of samples, such as 25-, 10-, and 1-ng dots, since the densities observed under our experimental conditions were not quantitative, as discussed below.

\section{RESULTS}

All of the DNA samples which we prepared in this study consisted of a relatively homogeneous population of fragment sizes, ranging in molecular weight from $3 \times 10^{5}$ to $1 \times$ $10^{6}$. Among the mycobacterial and nocardial strains, whose genome molecular weights ranged from $1.6 \times 10^{9}$ to $3.2 \times$ $10^{9}, M$. leprae had the smallest genome (Tables 1 and 2 ). The genome molecular weights of the corynebacteria examined were significantly smaller $\left(1.1 \times 10^{9}\right.$ and $\left.1.4 \times 10^{9}\right)$ than those of the mycobacteria and nocardia. The levels of DNA relatedness between $M$. leprae and other selected bacteria as determined by kinetic analysis are shown in Table 1 . Acidfast organisms isolated from wild armadillos and a mangabey monkey with leprosy-like disease contained DNAs which were indistinguishable from the DNA of $M$. leprae grown experimentally in armadillos. Thus, the organisms found in wild animals represent $M$. leprae.

In the kinetic analysis $M$. leprae showed 20 to $30 \%$ DNA relatedness with Mycobacterium tuberculosis, Mycobacte- rium bovis, Mycobacterium marinum, $M$. lepraemurium, and two strains of corynebacteria (Table 1). The DNAs of Mycobacterium gordonae, Mycobacterium scrofulaceum, Mycobacterium kansasii, Mycobacterium vaccae, and Nocardia otitidis-caviarum were related to the DNA of $M$. leprae at levels of 10 to $20 \%$, whereas Mycobacterium sp. strain ICRC and $M$. avium showed less than $10 \%$ relatedness to $M$. leprae.

In the dot blot hybridization experiments with $M$. leprae as the probe, the very weak signals observed after 2 days of exposure to $\mathrm{X}$-ray films reflected low degrees of hybridization. One week of exposure (Fig. 1) revealed appreciable intensities, although these intensities were by no means quantitative (4). In this experiment (Fig. 1) the majority of mycobacteria showed similar degrees of hybridization to $M$. leprae. However, $M$. tuberculosis appeared to be slightly more reactive than $M y c o b a c t e r i u m$ intracellulare, $M$. lepraemurium, $M$. avium, Mycobacterium sp. strain ICRC, $M$. scrofulaceum, and $M$. kansasii. Other mycobacteria showed significantly lower degrees of hybridization. The extents of hybridization between $M$. leprae and two strains of corynebacteria were as low as those of $E$. coli in dot blot hybridization experiments.

Table 2 shows the levels of DNA relatedness between $M$. lepraemurium and selected bacteria. Strains of $M$. avium showed more than $85 \%$ DNA relatedness to $M$. lepraemurium. Among the other mycobacterial strains, one strain of Mycobacterium microti (strain TMC 1601) showed a very high level of relatedness $(87 \%$ ), whereas another (strain TMC 1608) was significantly less homologous (9\%). In this connection, it must be mentioned that the DNAs of strains TMC 1601 and TMC 1608 are more than $95 \%$ homologous to those of $M$. avium TMC 706 and $M$. tuberculosis TMC 102, respectively. $M$. intracellulare, $M$. kansasii, and $M$. vaccae showed 30 to $50 \%$ DNA relatedness to $M$. lepraemurium, and all of the other strains showed less than $30 \%$ DNA relatedness to this species.

The effect of DNA fragment size on the calculated values 


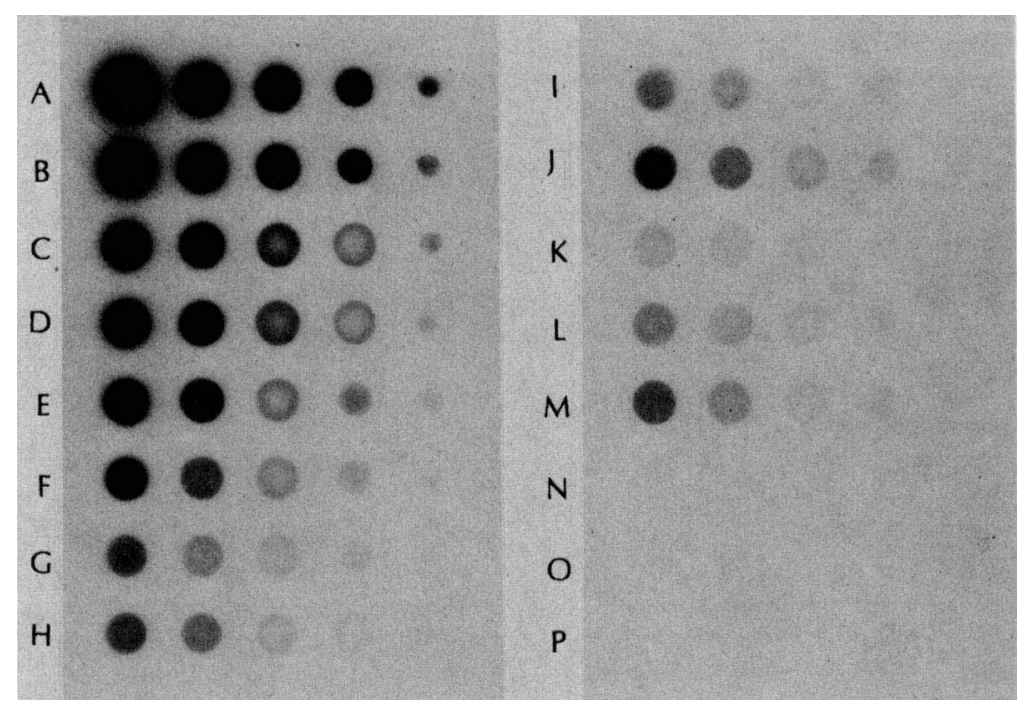

FIG. 2. Dot blot hybridization on a nitrocellulose filter. The order of test samples is the same as the order in Fig. 1. M. lepraemurium DNA was used as the probe. The X-ray film was exposed for 2 days.

of DNA relatedness was examined. When DNAs of $E$. coli and $M$. lepraemurium with fragment molecular weights between $3 \times 10^{5}$ and $1 \times 10^{7}$ were mixed at equal concentrations, the level of relatedness was calculated to be $36 \%$. On the other hand, sonicated samples with fragment molecular weights of $3 \times 10^{5}$ to $1 \times 10^{6}$, when mixed in an equimolar ratio, showed only $3 \%$ relatedness (Table 2 ).

In a dot blot hybridization experiment using $M$. lepraemurium DNA as the probe (Fig. 2), M. avium showed a significantly higher intensity of signals than other species at the 10- and 25-ng dots. A second group comprised of $M$. intracellulare, $M$. scrofulaceum, Mycobacterium sp. strain ICRC, and $M$. tuberculosis showed moderate signals, and all other strains tested revealed low degrees of hybridization. Dots containing DNAs of two strains of corynebacteria and $E$. coli were hardly visualized on this filter after exposure for 2 days to the $X$-ray film.

\section{DISCUSSION}

In this study we found significantly lower levels of DNA relatedness between $M$. leprae and the majority of bacterial strains tested than the levels reported previously $(5,6)$. In the latter experiments, DNA samples varying in molecular weight from $3 \times 10^{5}$ to $1 \times 10^{7}$ were mixed at equal concentrations for reassociation. In contrast, in this study we used equimolar mixtures of DNA samples which had been sheared into smaller fragments that ranged in molecular weight from $3 \times 10^{5}$ to $1 \times 10^{6}$. Since DNA relatedness was calculated by using the $\mathrm{C}_{0} \mathrm{t}_{0.5}$ value as a parameter, the higher relatedness values in the previous reports were most likely due to smaller $\mathrm{C}_{0} \mathrm{t}_{0.5}$ values derived from shorter times required for $50 \%$ reassociation, which occurred as a result of a zippering phenomenon during pairing of larger fragments (4). In fact, the model experiment with $E$. coli (genome molecular weight, $2.5 \times 10^{9}$ ) and $M$. lepraemurium (genome molecular weight, $1.8 \times 10^{9}$ ), which are taxonomically unrelated, showed an unrealistically high level of DNA relatedness $(36 \%)$ when larger DNA fragments were mixed at the same concentration. On the other hand, an equimolar mixture of smaller fragments resulted in a very low degree of relatedness $(3 \%)$, which was also demonstrated by dot blot hybridization. The smaller genome size estimated in the previous report may also be explained in terms of smaller $\mathrm{C}_{0} \mathrm{t}_{0.5}$ values obtained by hybridization of larger fragments. Based on the experiments described here, the importance of using an equimolar mixture of two samples with relatively uniform sizes should be emphasized, especially when the genome sizes differ significantly. The ratios of homology calculated on the basis of genome size, as listed in Tables 1 and 2 , facilitate comparisons among organisms having varying genome sizes. However, these relatedness values may not reflect the degrees of exact base pairing of specific chromosomal regions; rather, they should be interpreted as average levels of DNA relatedness between two organisms.

Dot blot hybridization experiments in which we used $M$. leprae DNA as the probe showed low levels of relatedness between $M$. leprae and all of the strains tested. $M$. tuberculosis appeared to be closer to $M$. leprae among these strains. Some disagreements in the order of DNA relatedness between results of dot blot and spectrophotometric DNA hybridization assays can be explained as follows. The intensities of signals shown in Fig. 1 do not reflect quantitative differences because of the long period of exposure to X-ray films needed for visualization of weak reactions (4). In addition, the degree of DNA binding below $20 \%$ observed in kinetic analyses has only semiquantitative value (3).

Two corynebacterial strains exhibited very low levels of relatedness with $M$. leprae in dot blot hybridization experiments, whereas kinetic analysis showed relatedness with $M$. leprae at levels comparable to those of $M$. tuberculosis and $M$. kansasii. This disagreement may also be due to the inaccuracy of the spectrophotometric assay of DNA-DNA hybridization between two samples with very low homology, as discussed above.

In this study, the levels of DNA relatedness between $M$. lepraemurium and other bacteria also differed from the levels observed previously (5), as discussed above. Nonetheless, $M$. avium still showed the highest level of DNA relatedness (about $85 \%$ ) with $M$. lepraemurium, as shown in the dot blot hybridization experiment (Fig. 2), suggesting a close phylogenetic relationship of these species. Among the strains not tested previously, one strain of $M$. microti (strain 
TMC 1691) showed a very high level of relatedness with $M$. lepraemurium, whereas another (strain TMC 1608) was less homologous. In this connection, it must be mentioned that the DNAs of strains TMC 1601 and TMC 1608 are homologous to those of $M$. avium and $M$. tuberculosis, respectively.

In dot blot hybridization experiments using $M$. lepraemurium DNA as the probe, the order of relatedness differed slightly from the order observed in the kinetic analysis, probably due to the reasons discussed above.

In conclusion, in this study we demonstrated the usefulness of the dot blot hybridization method for analysis of DNA relatedness among mycobacteria. This method particularly facilitates the screening of many test organisms for estimation of DNA relatedness with fastidious species, such as $M$. leprae and $M$. lepraemurium, since it requires a very small amount $(1 \mu \mathrm{g})$ of DNA for the preparation of probes.

\section{ACKNOWLEDGMENTS}

We greatly appreciated discussion with $\mathrm{L}$. Barksdale. We also thank C. A. Giardina for technical assistance.

This investigation was supported by grants from the World Health Organization and the Heiser Program for Research in Leprosy.

\section{LITERATURE CITED}

1. Bapat, C. V., K. J. Ranadive, and V. R. Khanolkar. 1961. Growth characteristics of an acid-fast Mycobacterium isolated from human lepromatous leprosy. Int. J. Lepr. 29:329-342.

2. Beaman, B. L., K. S. Kim, M. A. Laneelle, and L. Barksdale. 1974. Chemical characterization of organisms isolated from leprosy patients. J. Bacteriol. 117:1320-1329.

3. De Ley, J., H. Cattoir, and A. Reynaerts. 1970. The quantitative measurement of DNA hybridization from renaturation rates. Eur. J. Biochem. 12:133-142.

4. Freifelder, D. 1982. Physical biochemistry. Freeman and Co., San Francisco.

5. Imaeda, T., L. Barksdale, and W. F. Kirchheimer. 1982. Deoxyribonucleic acid of Mycobacterium lepraemurium: its genome size, base ratio, and homology with those of other mycobacteria. Int. J. Syst. Bacteriol. 32:456-458.

6. Imaeda, T., W. F. Kirchheimer, and L. Barksdale. 1982. DNA isolated from Mycobacterium leprae: genome size, base ratio, and homology with other related bacteria as determined by optical DNA-DNA reassociation. J. Bacteriol. 150:414-417.

7. Kafatos, F. C., C. W. Jones, and A. Efstratiadis. 1979. Determination of nucleic acid sequence homologies and relative concentrations by a dot blot hybridization procedure. Nucleic Acids Res. 7:1541-1552.

8. Meyers, W. M., G. P. Walsh, H. L. Brown, Y. Fukunishi, C. H. Binford, P. J. Gerone, and R. H. Wolf. 1980. Naturally-acquired leprosy in a mangabey monkey (Cercocebus sp.). Int. J. Lepr. 48:495-496.

9. Rigby, P. W. J., M. Dieckmann, C. Rhodes, and P. Berg. 1977. Labeling deoxyribonucleic acid to high specificity in vitro by nick translation with DNA polymerase I. J. Mol. Biol. 113:237-251. 